ference about the operation of workers' self-management. The tendency for whitecollar workers to be too heavily represented on workers' councils and management boards for their proportion of the labor force, drawn from chapters 4 and 5 on the prereform mechanics of wage determination, is assumed but not shown to lie behind the "efficiency fetish," to use the author's pejorative phrase, that has prompted the widening of interindustry wage differentials. The origins of the author's concern with narrowing this gap even at the expense of efficiency, and of his indifference to the recent Yugoslav goals of raising industrial production and export capacity without inflation, may be found in chapter 2 . There he juxtaposes but does not connect the Yugoslav experience with the diverse and largely nonMarxist tradition of "participatory"-that is, decentralized-socialism. Wachtel himself argues that this tradition is best represented by the syndicalist, Guild Socialist, and New Left writings. But these schools seek to redistribute power equally in an already developed economy and suggest a retreat from the wider marketplace regardless of the consequences for growth. The twentieth-century Marxist commitment to rapid industrialization has surely been much more important in shaping the theory and practice of Yugoslav socialism.

JOHN R. LAMPE

University of Maryland

\title{
A HISTORY OF MACEDONIA. Vol. 1: HISTORICAL GEOGRAPHY AND PREHISTORY. By N. G. L. Hammond. Oxford: Clarendon Press, 1972. xix, 493 pp. 20 figures. 23 maps. $\$ 38.50$. $£ 13.00$ net in UK.
}

A History of Macedonia is a nussive tome. A study of this scale is indeed, as the author modestly puts it in the introduction, "at least a novelty." Neither the geography nor the prehistory of Macedonia has ever been presented in such detail.

In part 1 the author describes the physical features of the province of Macedonia and her neighbors-the territory drained by the two great rivers, the Haliacmon and the Vardar (Axios) - and the surrounding area, Albania, Thessaly, and Thrace. He rightly regards Macedonia as a geographic entity, different from Greece and related to the continental land mass of the Balkans. In the beginning of the book there is a concise outline of physical features. The two hundred pages which follow give a detailed historical reconstruction of each province of Macedonia (divided into northwestern, western, and southern areas; the central plain; and hinterlands west and east of the Axios), including seventeen maps and meticulous documentation. The author presents the landscape of each section as it was during each phase of classical antiquity, describing roads, trade routes, and mountain passes and how they affected the systems of social organization at various times.

Part 2 is dedicated to the prehistory of Macedonia, from Paleolithic times to 550 B.c.- an accomplishment possible only after long and demanding labor. Heurtley's Prchistoric Macedonia (1939) was hitherto the only available source of information on the region-it covers, however, only Greek Macedonia, exclusive of Yugoslav Macedonia. The present volume deals comprehensively with the country as a whole. Mr. Hammond has pieced together an incredible amount of information from Yugoslav, Greek, and Albanian publications to present a complete panorama of the prehistory of the entire province. His consideration of geographical problems in relation to the interpretation of archeological materials is 
particularly valuable and revealing. The combined approach enhances the understanding of the processes of formation and distribution of cultural entities.

Paleolithic Macedonia is as yet virtually unknown, and reports on recent systematic research of Neolithic sites (Anza, Servia, Sitagroi, and Dikilitash), which provide information concerning the origin, duration. and chronology of the Neolithic and Chalcolithic civilizations, are as yet unpublished. Hammond has perforce been obliged to form his conclusions on anticuated material, especially with regard to the problems of Neolithic origins, migration, and imports. In view of the paucity of recent findings to which Hammond has access, it is not surprising that his view of the (Anatolian) origins of Neolithic (Sesklo) and Chalcolithic (Vinča) cultures are not consonant with the latest findings. His presentation of practically all the available published material from Albania deserves special commendation, since his book constitutes the initial appearance of this material in English.

The period which begins with the decline of the advanced and flourishing preIndo-European civilization and the subsequent Bronze Age is the time Hammond knows best and deals with most authoritatively. Around 3000 B.c. (or before, in the reviewer's opinion) a series of Kurgan (tumulus) graves in Macedonia and Albania signal the presence of invaders from the north. Hammond's descriptions of these mortuary chambers with cobblestone floors, containing contracted skeletons with typical Kurgan equipment, clearly illustrate the path of Indo-European diffusion into Macedonia and as far as lowland Albania. In this respect Hammond's book throws considerable light on the problem of the origin of the Macedones and other tribes which belong to the earliest genealogy of the Greek race-namely, the Ionians, Aeolians, Dorians, and what were called by Hecataeus "Molossika ethne." In the course of generations, in the period between the middle of the third millennium and the beginning of the second millennium B.c., these intruders continued to push their way to the south, to central Greece and the Peloponnesus, by sea and by land. They are identified with the earliest Greek-speaking peoples, the Ionians and the Aeolians.

The chapter on the Late Bronze Age includes information on contacts of Macedonia with the Mycenaean world, Troy, and Central Europe. New southward movements from Central Europe (that is. the Middle Danube region, not "Lausitz" as the author terms it, following earlier writers) are perceptible in the archeological record in the twelfth century в.C.; these newcomers are identified as the Phrygians. The chapter which deals with the advance of the Phrygians and their consolidation of power is among the strongest in the book, providing as it does background for the complexity of subsequent ethnic and linguistic ramifications in Greece and Turkey. The author clarifies the infiltration of the Dorians into southern Greece, of the Phrygians into Turkey, the subsequent Illyrian penetration into the southern Balkans and Italy ( $800-650$ B.c.), and the Cimmerian and Scythian movements from north of the Black Sea. Throughout the explications of this unrestful early Iron Age period, so essential for the understanding of ethnic configurations of the Balkan Peninsula, Macedonia remains the focal point of interest.

In my opinion A History of Macedonia is an essential volume in the library of every linguist, historian, and archeologist whose concern is the area in question.

Marija Gimbutas

University of California, Los Angeles 